\title{
Eski Uygurlarda Devlet, Adalet ve Saadet
}

\author{
Murat Elmali ${ }^{*}$,** \\ (İstanbul)
}

\begin{abstract}
Özet: Dünya üzerinde kurulan devletler, temellerini ne zaman ki adalet ve milletlerinin saadeti üzerine inşa etmişlerse o devletler uzun soluklu olmuş aksi halde ilk firtınada sarsılmışlar ve dünya tarihinden silinmişlerdir. Devlet-adalet-saadet kavramlarının birbiriyle olan yakın ilişkisi insanlık tarihinin hemen her döneminde pek çok alanın konusu olmuş ve pek çok ilmî çalışmada yerini almıştır. İnsanlar arasında adaleti kurmak ve dolayısıyla insanların huzurunu sağlamak amacına yönelik toplumsal bir teşkilatlanma olan devlet "èl", Eski Uygurca metinlerde kut ve törü/nom kavramları ile yan yana yer almıştır. Bu kavramlar Budist kültürün etkisiyle Eski Uygurca metinlerde Teyri Burhan-nom törü (Dharma)-Burhan kutı ile sembolleştirilmiştir. Bu metinlerin büyük bir çoğunluğu dinî metinlerdir. Halka hitap etmek, onları Buda saadetine ulaştırmak bu metinlerin en önemli amaçlarıdır. Metinler her ne kadar soyut bir Buda/Budizm ideali ortaya koysalar da öğreti metinlerindeki örnek hikâyelerde ve diğer anlatılarda günlük yaşama dair göndermeler de vardır. Eski Uygurca sivil belgeler ise doğrudan hayata dair metinlerdir ve bu metinlerde biz her üç kavramın somut karşılığını doğrudan görebiliriz. Gerek Budist Uygur dinî metinlerinde gerekse sivil belgelerde devlet-adalet-

\footnotetext{
* Doç. Dr., İstanbul Üniversitesi Edebiyat Fakültesi Dilbilimi Bölümü, melmali@istanbul.edu.tr; 0000-0002-2642-2127.

** Bu çalışma, Bilecik Şeyh Edebali Üniversitesinde 23-24 Ekim 2017 tarihinde gerçekleştirilen "Dil, Tarih ve Kültür Bağlamında Türklerde Devlet Yönetimi Ve Algısı" sempozyumunda sunulan bildirinin yeniden gözden geçirilerek genişletilmiş hâlidir.
}

Received: 9.12.2020; $\quad$ Accepted: 22.12.2020;

Published: 31.12 .2020 
saadet kavramlarının ele alınışı Uygurların eski Türk geleneğindeki Tẹri-törü-kut anlayışının farklı bir şekilde yansımasıdır. Gelenek devam etmekte fakat Uygurların içine girmiş oldukları yeni kültür dairesi geleneğin tarzını değiştirmektedir. Tegri-törü-kut anlayışı Budist kültürden hareketle Burhan-nom törü (Dharma)-Burhan kutı anlayışı ile varlığını devam ettirmiştir. Bu çalışmada Eski Uygurca metinlerden hareketle bu üç kavram ele alınmış, Eski Uygurların devlet yönetimi ve algısı anlaşılmaya çalışılmıştır.

Anahtar sözcükler: Uygur, Eski Uygur Türkçesi, èl, törü, kut

\begin{abstract}
State, Justice and Happiness In Old Uyghurs
When states depend on the principles of justice and the welfare of their people while being established, they last for long; otherwise, they get erased from world history. The terms "state-justicewelfare" have always attracted attention in many fields of study. $\dot{e}$ "state", which is an organization established to provide the people with justice and to keep the peace among them, was always pronounced side by side with the terms kut and törü/nom. Under the influence of the Buddhist culture, these terms changed into Tengri Burhan-nom törü (Dharma)-Burhan kutı. Giving sermon to the people and help them reach the peace of Buddha is the purpose of these texts. Although the religious texts presented an abstract ideal of Buddha/Buddhism we can find some references to the daily life in the exemplary stories and other narratives in these texts. The civil texts, on the other hand, deals directly with the daily life affairs, so one can find some solid instances of all these three terms in practice. The way that these terms, namely "statejustice-welfare", are handled in both the religious and civil texts of the Buddhist Uyghurs, reflects Uyghurs' understanding of tengritörü-kut. The tradition continued, but the new culture Uyghurs adopted changed the style of the tradition. The tradition of tengritörü-kut continued as Burhan-nom törü (Dharma)-Burhan kutı under the influence of Buddhist culture. This study deals with these three concepts on the basis of Old Uyghur texts and tries to understand how Ancient Uyghurs ruled their states and how they perceived these terms.
\end{abstract}


Key Words: Uyghurs, Old Uyghur Turkish, èl, törü, kut

\section{Giriş}

Tarihin bilinen ilk dönemlerinden bu yana pek çok milletin devlet tecrübesi olmuş ve bu tecrübeler onların tarihini meydana getirmiştir. Milletlerin varlığı kimi zaman kurmuş oldukları devletlerin varlığı ile mümkün olmuş, tarihte varlığından haberdar olduğumuz pek çok millet belki de devlet olamadıklarından tarih sahnesinden çekilmiştir. Günümüzde dünya üzerinde iki yüzün üzerinde devlet ve bu sayıdan çok daha fazla millet/ulus bulunmaktadır. Uluslararası arena, devlet olamayan bu milletlerin zaman zaman devlet olma mücadelesine ve arzusuna tanıklık etmektedir. Devlet olmanın önemini asırlar önce kavrayan Türk milleti, devlet tecrübesini tekrar tekrar yaşamış ve tarihinin büyük bir bölümünü bu tecrübelerle oluşturmuştur. Türkler, diğer dünya milletlerinde olduğu gibi devletin temelini adalet ve milletin saadeti üzerine inşa ettikleri zaman, devletleri uzun soluklu olmuş aksi hâlde binbir zahmetle kurulan devletler ilk firtınada sarsılmaya başlamıştır. Bir devletin yaşamını devam ettirmesini ve ayakta kalmasını bu iki kavramla sınırlandırmak mümkün olmasa da bu iki kavram her devletin olmazsa olmazıdır. Üzerinde durulacak olan her üç kavram da oldukça derin ve çetrefilli kavramlardır. Devleti siyaset bilimcilere, adaleti hukukçulara, saadeti ise anlam bilimcilere bırakmak en doğru olanıdır. Bununla birlikte her üç kavramın birbiriyle olan yakın ilişkisi insanlık tarihinin hemen her döneminde pek çok alanın konusu olmuş ve pek çok ilmî çalışmada yerini almıştır. Eski Uygurların devlet anlayışının anlaşılabilmesi için bu kavramlar Eski Uygurca metinler incelenerek yeniden ele alınmıştır.

$\mathrm{Bu}$ çerçevede ele alınacak ilk kavram devlet kavramıdır. Devlet kavramının sözlükteki karşılığı: "1. huk. ve top. Toprak bütünlügüne bağlı olarak siyasal bakımdan örgütlenmiş millet veya milletler topluluğunun oluşturduğu tüzel varlık. 2. Bu tüzel varlığın yönetim organları. 3. mec. Büyüklük, mevki. 4. mec. Mutluluk: Halk içinde muteber bir nesne yok devlet gibi / Olmaya devlet cihanda bir nefes sthhat gibi -Muhibbi. 5. mec. Talih." (TDK Güncel Türkçe Sözlük) şeklindedir. 
Türkçede genel itibari ile terim anlamı "tüzel varlık" ile anılan ve kullanılan devletin "baht, talih ve büyük mutluluk" anlamları, "millet olarak hukuki ve siyasi bir teşkilatlanma" için neden bu kavramın tercih edildiği hakkında ipuçları vermektedir. Devlet sahibi olmanın milleti, dertlerden, sıkıntılardan kurtarıp dirliğe, birliğe ve iriliğe ulaştıracağı beklentisi, talih ve mutluluk umudunun kaynağıdır. Devlet kavramı ile nerede ise her zaman beraber anılan adalet kavramı "Ar. (ada:let) 1. Yasalarla sahip olunan hakların herkes tarafından kullanılmasının sağlanması, türe. 2. Hak ve hukuka uygunluk, hakkı gözetme, doğruluk, türe. 3. Bu işi uygulayan, yerine getiren devlet kuruluşları. 4. Herkese kendine uygun düşeni, kendi hakkı olanı verme, doğruluk." (TDK Güncel Türkçe Sözlük) anlamları ile devletin tamamlayıcısı, bütünleştiricisidir.

Kisacası "Devlet, insanlar arasında adaleti kurmak amacina yönelik toplumsal bir teşkilatlanmadır" (Köseoğlu 1997: 32). Devlet, insanlar arasındaki her türlü sömürüyü önlemek, zulmü yok etmek ve böylece adaleti sağlamakla sorumludur. Devletin birey ve toplum karşısındaki tutumu, kişinin kendini geliştirmesi için imkân hazırlayıcı olması ve bireyin, başkalarını amaçtan saptırma çabası karşısında yasaklayıcı ve bireyi koruyucu olması şeklinde ortaya çıkar. Adalet için var olan devlette egemenlik zorunlu olarak bu amaçları belirleyen hukuk kuralları ile sınırlı olacaktır (Köseoğlu 1997: 34).

Adalet kavramının "Herkese kendine uygun düşeni, kendi hakkı olanı verme, doğruluk" karşılığı, devletin "Büyük mutluluk. Kut, talih. Büyüklük, mevki." anlamlarına hizmet etmekte, her iki kavram anlam ilişkileri açısından diğer bir kavram olan saadetin “Ar. (saa:det) Mutluluk." (TDK Güncel Türkçe Sözlük) anlamında birleşmektedirler.

Doğu geleneğinde, adalet mutlak iktidar sahibi olan hükümdarın iyi insan olmasından kaynaklanan bir lütuftur. Türk düşüncesinde ise halk için hak, hükümdar için meşruiyetinin temelidir. Tanrı'dan kut alarak tahta oturan kağan töreden şaşarsa Tanrı "kut yülek"ini çeker. "Kut" kişiye verilmiş sürekli bir mazhariyet değildir. "Erdemsizden kut çekilir." Töreye uyulmazsa ve töre unutulursa $\dot{e} l$ de dağılır. Esasta "él gider töre kalır". Bir gün yeniden Tanrıdan "kut" alan bir hakan bu töreye göre èli kurar, açları doyurur, çıplakları 
giydirir, az milleti çok eder. Ama töre kaybolursa èl de gider (Köseoğlu 1997: 49).

Kut ve kutluluğun yani devlet, ikbal ve ululuğun Türk hakanları ile kişilere, Tanrı tarafından verildiğine inanılıyordu. Tanrı insanlara yalnızca kut vermiyor aynı zamanda yarlıg, (emir ve istek), ülüg (baht ve talih), küç (güç ve gerekli enerji) de veriyordu. Orhun yazıtları başarıyı kutum bar üçün ülügüm bar üçün (KT: D29) gerekçesine dayandırırlarken erdemim üçün (KÇ: 7, 12) diyerek erdem gerekçesini de ekliyorlardı. Kut ve kutluluğu incelerken birbirine çok yakın bu tanrı vergilerini de gözden uzak tutmamak gerekir (Ögel 1982: 175-176).

Iduk/ldok kut "mukaddes kut" söz öbeği Uygur kağanlarına verilen unvanlardan biridir. Mukaddes, mübarek, kutsal, ilahi anlamındaki $\imath d u k / \imath d o k, \imath d$ - "gönder-" eyleminden gelen (Ölmez 2017: 119) Tanrı tarafından gönderilmiș olan bir șey daha doğrusu kutsallığın tam kendisidir. Bundan dolayı $\imath d u k-k u t$ veya $i d i k u t, k u t$ veya kutluluk yani devlet, ikbal ve ululuk üzerine kurulmuş "kader" ile ilgili olması kuvvetle muhtemeldir. Kutluluk kișinin davranışına göre gelip gidebilir. Fakat $\imath d u k$-kut üzerine geldiği insanın vücut ve davranışlarını da kutsallaştırmış olmalıdır (Ögel 1982: 179).

Kaşgarlının devlet anlamını kut kelimesi ile karşılaması, yazıtlarda ve Uygur metinlerinde kut kavramının "saadet, uğur, baht" gibi anlamlarının yanında "devlet ve siyasi egemenlik" gücünü ifade etmek üzere de kullanılması "Devletli olma ikbal ve saadet sahibi olmadır." düşüncesini açık bir şekilde ortaya koymaktadır (Köseoğlu 1997: 46). Bu düşünce "devletlü ve saadetlü Osmanlı padişahları"na kadar uzanmakta ve günümüzde dahi anılmaktadır.

$\mathrm{Bu}$ üç kavramın hem anlam açısından hem de birey ve toplum hayatındaki işlevleri açısından birbirleri ile olan yakından ilişkileri, bu kavramların çok derin bir tarihe sahip olduğunun ipuçlarını vermektedir. Türk dilinin yazılı dönemlerinin en eski ve en zengin dönemlerinden olan Eski Uygurca dönemi bu kavramları, bu kavramların kullanım alanlarını, bunların birbirleriyle olan ilişkilerini anlamak açısından önemli veriler sunmaktadır. Bu dönemden elde edebilecek bilgiler gerek devlet gerekse adalet ve saadet kavramlarının anlaşılmasına daha da yardımcı olacaktır.

Eski Uygurca metinler genel olarak Budist Uygur Nesri (1. Anlatılar, Masallar; 2. Sūtralar; 3. Abhidharma Metinleri; 4. Vi- 
nayalar; 5. Tövbe Metinleri; 6. Büyü Metinleri; 7. Çeşitli Metinler) Manihaist Uygur Nesri, Hristiyan Uygur Nesri, Din Dış1 Çeşitli Metinler ve Uygur Şiiri (Ölmez 2017: 209-233) şeklinde tasnif edilmektedir.

Sivil belgeler bir yana bırakılırsa Budist Uygur edebiyatının esasını çeviri eserler oluşturmaktadır. Bu eserlerin çok az bir kısmı özgün, telif eserlerdir. Çoğunluğu ise Budist külliyata ait çeviri eserlerdir. Tripițaka adlı Budist külliyatın içerisinden Uygurcaya çoğunlukla Sūtralar çevrilmiştir (Ölmez 2017: 209-210).

Ele alınacak kavramlar daha çok bu edebiyatın ürünleri olan eserlerde geçmektedir. Gerek Manihaist Uygur nesri gerekse Hristiyan Uygur nesri Uygur edebiyatı içerisinde Budist Uygur edebiyatı kadar yer tutmamaktadır. Bundan dolayı yapılan bu çalışmada daha çok Budist Uygur edebiyatı eserleri taranmıştır. Bununla birlikte devlet, adalet ve hatta saadet kavramlarını ilgilendirmesi bakımından sivil belgeler ayrı bir önem arz etmektedir.

Eski Uygurlarda devlet, adalet ve saadet kavramları incelenirken dikkat edilmesi gereken bir diğer husus ise bu kavramların Uygurların hangi dönemini kapsadığıdır. Bilindiği gibi Uygurlar genel itibariyle Ötüken Uygur Kağanlığı ve bu kağanlık sonrası İpek Yolu bölgesinde, Turfan ve çevresinde kurulan hanlıklar şeklinde iki dönemde incelenmektedir.

III. Türk Kağanlığı olarak bilinen ve Türklerin kadim yurdunda kurulmuş olan kağanlık farklı isimlerle anılmaktadır. İpek Yolu bölgesinde, Turfan ve çevresinde yine Uygurlar tarafindan kurulan hanlıktan ayırt edilmesi için bu kağanlığa Uygur Bozkır Kağanlığı veya Ötüken Uygur Kağanlığı da denilmiştir. 744'te Köktürk kağanlığına son verip aynı bölgede hüküm sürmeye başlayan Uygurlar 840 yılına değin aynı sahada yaşamışlardır (Ölmez 2017: 2223). Kuzeyden gelen Kırgızlar, Uygurların Moğolistan'daki hâkimiyetine son vermiş ve Uygurlar Moğolistan'dan ayrılmışlardır. Uygurlar buradan Gansu (Ganzhou) ve Turfan bölgelerine göç ederek orada yeni devletler kurmuşlardır (Ölmez 2017: 27). 8501240 yılları arasında hüküm süren Uygur hanlığı Hoço Uygur Hanlığı olarak bilinmektedir. Moğolistan'dan ayrılarak bugünkü Şinciang bölgesine, Tarım, Hoço bölgelerine gelen Uygurlar burada yeni bir uygarlık oluşturmaya başlamışlardır. Yerleşik hayata 
geçen ve yeni bir hayat tarzı benimsemeye başlayan Uygurlar kendilerinden önce bu bölgeye yerleşen halklardan Budizmi, Manihaizmi, Hristiyanlığ kendi dillerine tercüme etmişlerdir. Esas olarak bugünkü Turfan çevresinde yoğunlaşan Uygurlar Beşbalık'a, Aksu'ya, Kumul'a uzanan geniş, bir bölgede Budist ağırlıklı bir çeviri edebiyatı oluşturmuşlardır (Ölmez 2017: 189).

Eldeki belgelerin çoğunluğunu daha çok 840 sonrası metinler oluşturmaktadır. Bundan dolayı çalışmada ele alınacak kavramlar, Uygur Budist metinlerinde ve bu dönemden günümüze gelen sivil belgelerde aranmış, bu belgeler üzerinden değerlendirilmiştir. Dolayısıyla varılacak sonuçlar daha çok 840 yılından sonraki Uygur dönemini ilgilendirmektedir. Bu dönem metinleri her üç kavram açısından değerlendirildiğinde karşımıza çıkan kavramlar daha çok Budist Uygur kültürünü yansıtmakta ve Uygur Budizmini ilgilendirmektedir.

\section{Eski Uygurca Eserlerde "devlet"}

"Belli sınırlar içindeki insan topluluğuna ait siyasi hâkimiyetin teşkilatlanmış şekli." şeklinde tanımlanan devlet kavramı Arapçada devlet veya dûlet "değişmek, bir halden başka bir hale dönmek; nöbetleşe birbiri ardınca gelmek, dolaşmak; üstün gelmek, zafer kazanmak" anlamlarına gelmektedir. Devlet kelimesinin siyasi bir kavram hâline gelmesinin ilk aşamada kazandığ 1 anlam "zafer, güç" veya "hâkimiyetin dönüşümlü olarak el değiştirmesi" şeklindedir. İkinci aşamada devlet kelimesi hâkimiyetin değişmesinden çok sürekliliğini ifade eden bir kavram hâline gelmiş, nihaî siyasi otorite ve yapı için kullanılmaya başlanmıştır. Osmanlı Devleti'ni ifade eden Devlet-i Al-i Osmân tabiri de bu aşamadaki anlam sürekliliğini yansıtmaktadır. Ancak "devlet-i ebed-müddet" şeklindeki kullanımda bir taraftan gücün ve zaferin, diğer taraftan siyasi yapının sürekliliği vurgulanmıştır. Üçüncü aşama ise devlet kelimesinin çağdaş siyaset literatüründeki kullanımında kendini göstermektedir. $\mathrm{Bu}$ aşamada kavram tamamiyla millet-devlet (nationstate) esasına dayalı "milletlerarası sistemin her bir unsuru" anlamını taşımaktadır (Davutoğlu 1994: 234-235).

Siyasi düşünce tarihinin en eski ve en temel meselelerinden biri de devletin, dünya görüşü ile sosyo-politik kültür arasındaki teorik 
konumu ve tarihî gerçeklik içindeki pratik oluşumudur. Devlet, Eflâtun için filozof-kralın gerçek hakkındaki bilgisinin ve insan ruhunun ideal bir form halinde tecessüm etmesidir. Aristo için ferdin siyasi bir varlık olarak mensup olduğu organik bütünlüktür. Hobbes için insanın ontolojik varlığını güvence altına alan siyasi güç yapılanmasıdır. Rousseau için toplumun ortak iradesini temsil eden siyasi birliktir. Hegel içinse Tanrı'nın yeryüzündeki yansıması ya da mutlak ruhun (geist) tarih içindeki tecessüm etmiş şeklidir. Tarihî süreç içerisinde devlet kavramın çok çeşitli tanımlarının yapıldığı görülmektedir. Bununla birlikte bu süreç içinde iki ana kutba doğru bir meylin varlığ 1 açık şekilde görünmektedir. Birinci meyil, devleti mahiyeti ve özü itibariyle mutlak değer ifade eden soyut ve aşkın bir kurum olarak görmektedir. Eflâtun'un ideal devletinde ilk özgün ifadesini bulan bu yaklaşım, Hegel'in kapsamlı felsefi sisteminde en keskin formülüne ulaşmıştır. İkinci meyil ise devleti belli sosyal işlevleri üstlenen bir siyasi üst kurum olarak kabul etmektedir. Pragmatist felsefenin devlete yaklaşımını aksettiren bu görüşte devletin kendisi değer belirleyici değil sivil toplumun ürettiği değerlerin yaşanır hâle getirilmesinde aracı konumundadır (Davutoğlu 1994: 235).

Eski Uygur Türkçesi metinlerinde daha çok èl, uluş; èl törü, èl uluş kelimeleri ile ifade edilen devlet kavramını karşılayan diğer bir terim ise "Teker döndüren krallığı" anlamında kullanılan cakravartī ya da cakravartīrāja'dır.

"Teker döndüren kral" anlamında kullanılan cakravartī ya da cakravartīrāja, Hint mitolojisinde ideal krallık olarak gösterilir. Terim, çakra "teker", vartin ya da vart̄̄ "döndüren" kelimelerinden oluşmaktadır. Budizm'de "dünyaya barış, ve adalet getiren" anlamındadır (Tokyürek 2019: 191).

ol balıkta çkrvrt tiziginte gaudam uguştın tözdin belgürmiş kamag şaki tözlüg bodun bokun üze erklig türklüg şudotan atlig hormuzta teyrike yüleşi èlig han bar (Tekin 1976: 60-61 13/44-51) "O şehirde Cakravartī cevherinde Gautama soyundan ortaya çıkmış bütün Śakya esaslı topluluk 2 üzerine güçlü 2 Śtdhodāna adlı Brahmana tanrıya benzer hükümdar ${ }_{2}$ vardır." (Tokyürek 2019: 191).

$k(a)$ ltı altun tilgenlig çakravart èlig hanlarnı̀ alp er erdinisi tört törlüg süülüg kuvragın neteg öz erkinçe tapınça evirer erser ,, 
„, ançulayu y(e)me bodis(a)t(a)vlar bo köyül küçi üze arlg süzük burhanlar uluşın ețmekig tuyunup ,, ,, ol tuyunmakları küçințe ötrü yinçürmek aḍırtlamaklıg küçin ,, ,, bışrunmak ögretinmeklig küçin bo èki törlüg küç küsün üze erkinçe tapınça tınl(l)glarka asıg tusu kılmakın küçenürler küçlenürler ,, ,, (Tokyürek 2018: 344-345) "Eğer altın tekerlekli Cakravartī hükümdarın komutanının dört türlü ordu topluluğunu nasıl kendi gücünce istediği gibi, arzuladığ1 gibi çevirirse Bodhisattvalar (da) bu gönül sayesinde temiz ${ }_{2}$ Budalar alanını süsleyip anlayıp o anlamaları sayesinde (de) saygı (ve) ayırma gücü ve öğrenme ${ }_{2}$ gücü ile bu iki türlü güç kuvvet üzerine arzuladığı gibi canlılara fayda ${ }_{2}$ sağlamayı güçlendirirler, güçlenirler." (Tokyürek 2018: 565).

Devlet kavramını karşılayan Skr. kökenli "teker döndüren krallık" çakravart cevheri yukarıdaki örneklerde de görüldüğü üzere Buda'nın soyuna telmihen devletin temeli olarak Buda'ya dolayısıyla Budizm idealine işaret etmektedir. Burada devlet Budizm ile soyut bir kavram olarak karşımıza çıkmaktadır. Daha önce bahsedildiği gibi devlet kavramının tarih içinde evrildiği iki ana kutuptan "mahiyeti ve özü itibariyle mutlak değer ifade eden soyut ve aşkın bir kurum" tanımlamasına yaklaşmaktadır. Bununla birlikte gerek sivil belgelerde gerekse dinî metinlerde zaman zaman karşılaşılan él, uluş kelimeleri ve devlet kavramı ile ayrılmaz bir kullanım alanı bulan $\dot{e}$, han, hatun vb. kelimeler ile ifade edilen devlet farklı bir yöne ilgimizi çekmektedir.

èlig törüg agı barım tutar "devleti ve devletin kurumlarını zenginlik ayakta tutar" (Hamilton 1998: 15 IX).

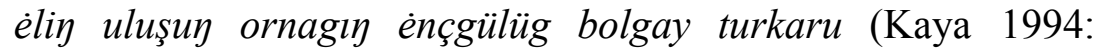
305567/8-9) "devletin daima huzurlu olacak".

bo buyanıy arış arıg edgülüg tüşinte bodisatav uluşlug kagan hatun tüg tümen yaşasın "bu sevabın saf iyiliği neticesinde dindar memleketli han hatun sayısız yıl ömür sürsün” (S. Şen 2002: 134).

birök kayu èlig hannıy èli uluşı içinte bilser körser kılmışın nomsuz törüsüz kılınçıg raçaşastır törüsinçe kavırmış kergek yazuklap (Kaya 1994: 302561/7-12) "eğer her hangi bir hükümdar, devletinde kanunsuz işler yapıldığını görürse hükümdarlar kanuna göre (hükümdarın bunu) ayıplaması ve (ülkeyi) toparlaması gerekir". 


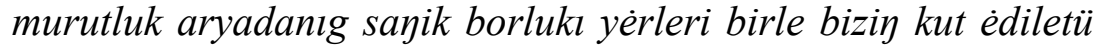
$y(a) r l(\imath) k(a) p$ neçeketegi èl işsiz birtsiz [böz] siz titntsuysız kulturu başta bizi门 kutka basa èlke uluşka buyan bèrzün tèp "(Iduk) kutumuz, Murutluk Aryadan'1 Samghika bahçesi arazileri ile bağışlayıp buyurdu. Devlete karşı herhangi bir iş yapmadan, vergi vermeden, herhangi bir ödeme yapmadan arazi vergisi vermeden öncelikle (Iduk) Kut'a sonra devlete, memlekete (hizmet edip) sevap kazansın diye..." murutluk aryadanta turguçı şilavantilarnıり kiçigleri şelileri kuvragtın èltin boduntın işke küçke tartmagu kulturu $y(a) r l(l) k(a) d(l) m(l) z$. "Murutluk Aryadan'da duran Şilavantiler'in yardımcıları ve Şeliler'in devlet, halk ve cemaat tarafından bir işe alınmayacağı buyrulmuştur.” (A. Şen 2004: 210213).

Eski Uygur Türkçesi metinlerinden alınan bu örnekler devletin toplum ve halk ile olan ilişkisini daha iyi ortaya koymaktadır. Devlet bu ve benzeri örneklerde görüldüğ̈ gibi kurumları ile birlikte yüzünü halka dönmüştür. Devletin somut bir karşılığı ve kuşatıcılığı vardır. Bu bilgiler bize devlet kavramının tarih içinde ulaştığ1 ikinci bir anlayışı yani "devleti, belirli sosyal işlevleri üstlenen siyasi bir üst kurum" anlayışını ortaya koymaktadır.

Eski Uygurca İyi ve Kötü Prens isimli anlatıda geçen şu bölüm; devleti, devletin kurumlarını, devletin sosyal yönünü, devamlığını ve bütün bunların önemini göstermesi açısından önemlidir:

... kaltı ol ödün agıçı ulugı hanka inçe ötünti teyrim aglık bolkalır agl barım alkınsar uvatsar yazukka tüşe teginmegey

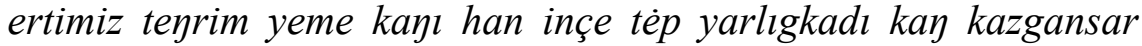

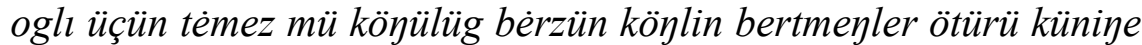
tıdıgsız berdi ol ödün ınançları buyrukları esşidip hanka inçe tèp ötüntiler tenrim èlig törüg agl barım tutar agl barım alkınsar èl törü neçök tutar biz teyrim "O zaman, hazine başkanı, hana söyle arz etti: "Efendim, hazine kurumak üzere. Eğer, zenginlikler ve varlıklar bitiyorsa, ufalıyorsa, hataya düşmez miyiz, Hünkârım." Bunun üzerine (prensin) babası han şöyle buyurdu: "Eğer baba kazanırsa oğlu içindir, denemez mi? (Oğlunun) arzusunu yerine getirsin (denmez mi?) Onun gönlünü kırmayın!” Bu durumda prens günlerce engel görmeden verdi. O zaman sadık dostları, bakanları, bunu işitince, hana şöyle arz ettiler: "Haşmetlim, devleti ve kurumlarını zenginlik ve servet ayakta tutar. Varlık ve zenginlik tükenirse, Devleti ve kurumlarını nasıl sürdürebiliriz, efendim?" 
(Hamilton 1998: 14-15 VII-IX).

\section{Eski Uygurca Eserlerde "adalet"}

Devlet anlayış ve yapısı hayata aksettirilmesi gereken hukuki bir zorunluluktur. Hukukun hayata geçirilmesi için devletin varlığ 1 kaçınılmazdır. Fakat bu zorunluluk katı yapılara dayalı bir siyasi gerçekçiliği beraberinde getirmez. Aksine yapıların ahlâki ve hukuki idealleri yaşatmak için var olduğu esası kabul edilir (Davutoğlu 1994: 238). Ahlaki ve hukuki idealler ise gerek birey gerekse toplum hayatında önemli bir yeri olan "adalet" kavramını ele almayı gerekli kılmaktadır.

Adâlet, "davranış ve hükümde doğru olmak, hakka göre hüküm vermek, eşit olmak, eşit kılmak" gibi anlamlara gelen bir masdarisimdir. Adâlet, İslâm felsefesinde, ontolojik bir kavram olarak ele alınmıştır. Bu kavram feyz veya sudûr sırasında her varlığın, kendi mertebesine göre "İlk Varlık"tan bir varlık payı alması şeklinde açıklanmaya çalışılmıştır. Buna göre Allah'ın adâleti, varlık hiyerarşisi içindeki durumuna göre var olan her şeye yansır ve bunlara tamlık ve mükemmellik kazandırır. Fârâbî, adâlet sıfatının Allah'ın zâtının dışında değil, cevherinde bulunan bir nitelik olduğunu belirtmektedir. Böylece İslâm filozofları adâletin, varlık sahnesinde yer alan her varlığın bütün gelişim safhalarında ve hatta her cüzünde tecellî ettiğini söylemişlerdir (Çağrıcı 1988: 341-342).

Devlet olabilmenin en önemli şartlarından biri adaleti sağlamaktır. Kurdukları devletlerle tarih sahnesinde önemli roller oynayan Türklerde hukukun üstünlüğü önemli bir kabullenişstir. İlahî iradenin dünyadaki temsilcisi konumundaki kağanın en üst kanun koyucu olduğu eski Türk devletlerinde (Golden 2002: 120) toplum hayatı törü denilen yasalar aracılığıyla şekillenmiştir (Ögel 1982: 326-336). Uygurlar 840 sonrasında göçtükleri Turfan bölgesinde de hukuka hassasiyetle riayet etmişler ve medeni bir hayat sürmüşlerdir. Turfan Uygurları zamanlarına göre hayli gelişmiş bir hukuk terminolojisi oluşturmuşlardır (Caferoğlu 1934: 1-43; Arat 1987: 506-572; S. Şen 2007: 240-241).

$\mathrm{Bu}$ hukuk terminolojisinin oluşumuna Uygur Budizminde oldukça ayrıntılı bir şekilde işlenen, sürekli vurgulan adalet ve kanun anlayışının yanında sosyal hayatın düzenlenmesi sürecinde ortaya 
çıkan adalet anlayışı da oldukça etkili olmuştur.

Eski Uygurca metinlerde hükümdar, çambuḍivip atl(l)g [u]lus,takı nomça törüçe kı]ltaçı èlig han .. ol inç[ip] erür ugrayu .. biz kamagunuy oglumuz "Çambudivip adlı ülkedeki öğretiye (ve) yasaya uygun davranan hükümdar ${ }_{2}$ kesinlikle hepimizin evladıdır." (Çetin 2017: 385-386) şeklinde anlatılır.

Yine bu metinlerde dünyevi ve uhrevi adalet birlikte düşünülmektedir: kim yme kişi ajunınta erken kişig tokıguçı toglaguçı erserler ogrt igit erserler ol tınlıgları seyet tamuda örtlüg yalınlıg temirlig çomakın bergen tokıyurlar töltürürler "İnsan âleminde iken insanları dövüp işkence eden iseler, hırsız ve dolandırıcı iseler böylesi canlilar sanghata cehenneminde alevden demir sopalarla dövülürler" (Ş. Tekin 1980: 205; S. Şen 2007: 322-323).

İnsan hayatını olumsuz etkileyen kanunsuzlukların da dinî motiflerle ele alındığı görülmektedir: alku kamag èlke uluşka nomka şazınka karşı ayagsızlıg ogrı karakçı yagı yavlaklarnı’ ayıg yavız sakınçlarıg kètzün tarıkzun "Bütün memlekete, öğretiye, şeraite karşı saygısızlık; hırsız ve haydut düşmanların kötü düşünceleri ortadan kalksın" (S. Şen 2007: 324).

Eski Uygur Türkçesi metinlerinde adalet, hukuk, kanun kavramları her ne kadar pek çok farklı kelime (boşgut, nom, toku, vap, törü, tokulug, törülüg; çahşaput törü, edgü ögli yarlıkançıçı könüllüg, nom törü, nomlug törülüg, raçaşastır tègme törü bitig, raçaşastır tègme begler törüsin, raçaşastır törü bitig, törü boşgut, törü toku, törülüg tokılıg, tsı törü) ile karșılansa da nom/dharma kelimeleri gerçek anlamları olan "öğreti” ile birlikte bu konuda en çok karşılaşılan kelimelerdir. Hemen hemen her Budist metnin başında yer alan namo buddaya namo darmaya namo s(a)ygaya: cümlesi Buddha, Dharmā ve Sangha'ya verilen bir selamdır. Buda, kanun (öğreti) ve topluluk (toplum) dolayısıyla din, hukuk ve toplum bir aradadır. Eserlerin daha giriş cümlesinde kendini gösteren bu ilişki adalet, kanun, düzen kavramlarının geçtiği her yerde kendini göstermektedir. Burada elbette nom/dharma kelimesi öne çıkmaktadır.

Budizm'in esas terimlerinden olan dharma, "korumak, desteklemek, saklamak" gibi anlamları olan dhri kelimesinden türemiştir. 
Terim geniş anlamda ise "kanun, gerçek, doktrin, Buda'nın öğretisi, emir, görenek, davranış, görev, erdem, din, adalet, yaratılış, nitelik, karakter, varlığın başlangıcı" gibi anlamları ifade etmektedir (Tokyürek 2019: 208).

Gerek tek başına gerekse farklı kelimelerle birlikte kullanılan ve kanun/adalet anlamin ifade eden nom/dharma, metinlerde adaletin temelinin nerede aranılması gerektiğine de işaret etmektedir:

anantaras ayıg kılınçıg .. burhanlarnıı y(a)rlıgl .. yavalturur bokurur .. "Anantaras günahlarını işleyenler varsa Budaların buyruğu (onları) kontrol altına alır, sınırlandırır." (Çetin 2017: 241).

bo köyül küçi ugrınta burhanlar yarlıgı çahşapud törünüy asıglıgın edgülügin tuyunup (Kaya 1994: 148207/2-4) "Bu gönül gücü sayesinde Buda'nın buyruğunu, kanununun faydasını ve iyiliğini anlarlar.".

on edgü kllınçlıg törüde boşgutta burhanlar yarlııınta kètmiş erürler "On sevap kanununda, öğretide Budalar hükmüne gitmişlerdir." (Bang-Gabain-Arat 1934: 126 271-272).

Metinlerde adaletin ve kanunun temeli Buda ve onun öğretisidir. Diğer bütün dünyevi konularda olduğu gibi adalet ve devlet nizamı hususunda da bu iki kavram merkezde yer almakta, Budist Uygurların dünyasını şekillendirmektedir.

ançulayu yime bodisatavlar bo köyül küçi ugrınta burhanlar yarlıgı çahşapud törünüy asıglıgın edgüligin tuyunup (Kaya 1994: 148 207/1-3) "Bodisatavlar, yine bu şekilde gönül güçleri sayesinde Budaların buyruğu olan kanunun faydasını kavrayı".

nomlug törülüg balıkta kèy alkıg orduda ondın sıyarkı burhanlar uluşıntın kelmiş erüş üküş bodisatav bo yerrteki tört türlüg tèrin kuvrag birle yarlıkayur "adaletin olduğu (adil) şehirlerde, geniş saraylarda, on tarafta bulunan Budaların memleketinden gelen sayisız bodisatavlar, burada dört türlü cemaatle birlikte buyuruyor" (Bang-Gabain-Arat 1934: 1047-9).

birök kayu èl hannıり èli uluşı içinte bilser körser kılmışın nomsuz törüsüz kllınçıg raçaşastır törüsinçe kavırmış kergek yazuklap "eğer herhangi bir hükümdarın ülkesi içinde kanunsuz işler yaptığını görse hükümdarlar kanuna göre (bunu) ayılayıp (ülkeyi) 
toparlamas1 gerek" (Çetin 2017: 194).

anta ötrü uluş ulugl tükel bilge biliglig teyri teyrisi burhan ol kamag tèrin kuvragka raçaşastır begler törüsin nomlayu yarlıkap yene inçe tép yarlıadı (Kaya 1994: 306570/9-15) "Bunun üzerine ülkenin saygıdeğer büyüğü, tam bilge tanrılar tanrısı Buda, hükümdarlar kanunu topluluğa vazederek yine şöyle buyurdu."

burhanlarnıy tsisınta törüsinte bolmak üze könüli taluy ögüz teg kè alkıg erti "Budaların adaleti yolunda olduğu için gönlü okyanus gibi engindi. (Zieme 2000: 82327-330).

Turfandaki Uygurlardan kalan dinî eserlerde daha çok Budizm'in ideal hukuk anlayışının yansıtıldığı, bu inanç sistemini benimseyenleri ideal bir hukuk anlayışı ile irşat etme çabası hissedilmektedir. Bundan dolayıdır ki bu metinlerdeki adalet anlayışı Buda'dan ve onun öğretisinden (dharma) ayrı düşünülemez. Bununla birlikte dinî eserler kadar çok olmasa da Eski Uygurlardan günümüze kadar ulaşan sivil belgeler dinî metinlerden çok daha somut ve canlı bir yaşamı gözler önüne sermektedir.

$\mathrm{Bu}$ dönemden kalan hukuk belgelerinde ölüm, dayak, para, mal ve yasa cezaları kayıt altına alınmış (İzgi 1986: 90-93), böylelikle kişilerin hakları garantilenmiştir (S. Şen 2007: 241).

tojuz yıl onunç ay altı y(e) g(i)rmike. m(e)n ozmış togrıl ènim basa togrıl bileki alış berriş tıltagınta kıtay yalavaç alp turmış olar üskinte tişip alım berrim üzüştümüz . m(e)n ozmış togrll kèn öydün basa togrılka kimniๆ kayunı küçin tutup çam çarım kılsar m(e)n yasatakı kıınka tegir m(e)n . tanuk alp turmış tanuk vap togrıl $m($ e)n bacak ozmış togrılka ayıtıp bitidim bu tamga m(e)n ozmış togrılnıı ol "Domuz yılının onuncu ayının on altısında ben Ozmış Togrıl küçük kardeşim Basa Togrıl ile alışveriş sebebinden Kıtay Yalavaç Alp Turmış onlar huzurunda konuşup alım verim kesiştik. Ben Ozmış Togrıl şimdi veya daha sonra Basa Togrıl'a kim olursa olsun zorla tutarak itiraz etsem kanundaki cezaya uyarım. Tanıklar: Alp Turmış, Vap Togrıl. Ben Baçak Ozmış Togril'a söyleyip yazdım. Bu damga ben Ozmış Togrıl'ındır." (A. Şen 2004: 245).

Eski Uygurlardan kalan hukuk belgeleri sözleşme geleneğinin sözlü değil yazılı olduğunu göstermesi bakımından da son derece önemlidir. Yazılı sözleşme geleneği düzenli işleyen gelişmiş bir hukuk düzeninin varlığına da işaret etmektedir. Bu hukuk düzenin 
varlığı sağlam bir devlet teşkilatlanmasına tanıklık etmektedir. Günümüze kadar ulaşmış olan bu belgeler bize Uygur toplumunda gündelik hayatın parçası olan birçok iş ve işlem için belirli bir hukuk düzenine göre sözleşmelerin yapıldığını gösterir. Bu sözleşmeler, farklı konularda her iki tarafın da onaylamasıyla yapılır. Sözleşmelerde karşılıklı hak ve hukuku koruyan bilgilerin yanında, özellikle sözleşme ihlallerinde mağdur olanın korunmasına yönelik önlemler ve cezai uygulamalar da bulunmaktadır. $\mathrm{Bu}$ gibi ayrıntılardan hareketle Eski Uygur sözleşmelerinin, günümüz hukuk sözleşmeleriyle pek çok açıdan benzeştiği söylenebilir. Uygur sözleşmelerinde, sözleşmenin içeriğine bağlı olarak değişen bazı özellikler yanında, aynı üslup yapısının bulunması, aynı terimlerin kullanılması Uygurların sistemli ve gelişmiş bir hukuk anlayışının olduğunu da göstermektedir. Söz konusu sözleşmeler, Uygur döneminde özellikle devletin özel hukuk alanındaki rolünü anlamamıza da yardımcı olmaktadır. Sözleşmelerin büyük bir kısmında geçen bu cezai şartların benzer özellikler taşıması Uygur toplumunda düzenli olarak işleyen bir ceza hukuku anlayışının varlığını göstermektedir (Özyetgin 2014: 41-42).

Uygurlardaki hukuk sisteminin kaynakları günümüze kadar ulaşmamıştır. Buna ragmen sözleşmelerde hukukun dayandığ 1 resmî kanunlarla ilgili bazı ipuçlarını tespit etmek mümkündür. Sözleşmelerde geçen yasa-takı klyınka tegir men "yasadaki cezaya razıyım", yasa-takı kın-ka tegsünler "yasadaki cezaya çarptırılsınlar", bitig yosunca "sözleşme yasasına göre" gibi ibareler anayasa niteliğinde bir yasanın varlığına işaret etmektedir (Özyetgin 2014: 42).

Uygur sivil belgelerinde ceza uygulamalarına temel oluşturan iki kaynak vardır: Devletin başındakilerin koydukları resmî yasalar ve sözleşmelerde èl yayınca "il (ülke) kanuna göre" şeklinde geçen örfi yasalar (Özyetgin 2014: 43).

\section{Eski Uygurca Eserlerde "saadet"}

İslâm düşünürleri kâinatın her alanında bir düzenin var olduğunu kabul etmişler ve bu düzenin medeni varlıklar sayılan insanların birbirleri arasındaki ilişkilerde de aramışlardır. Buna göre sosyal hayat, bireyler arasında ortak münasebetler kurulmasıyla gerçekleşir. Cemiyet yapısının oluşması ve sağlıklı bir şekilde işle- 
yebilmesi için bu münasebetlerin, kanun (sünnet, şeriat/Budizm'de dharma) ve adâlet ilkelerine uygun bir şekilde düzenlenmesi gerekir. Bu durum bir kanun koyucunun ve adâleti icra edecek kurumların varlığını gerektirir. İbn Sînâ'ya göre evrenin düzenini sağlayan "ilk inâyet", toplum düzeninin sağlanabilmesi için adâleti gerçekleştirecek "sâlih bir insan"ın varlığını, böylece hayırlı bir sosyal düzenin kurulmasını mümkün kılmıştır (Çağrıcı 1988: 342).

Eski Uygur Türkçesi metinlerinde de gerek devletin sağlam temeller üzerine oturtulması, gerekse adaletin sağlanması saadete özellikle Tanrı ve dharma saadetine ulaşmış canlılarla mümkün olabilmiştir. Saadet hem bu iki kavramı beslemiş hem de bu iki kavramın tam manası ile işlemesiyle kendini daha da canlandırmıştır.

Saâdet "kısmetli ve talihli olmak, uğurlu gelmek" anlamındaki $s a$ 'd kökünden türemiștir. Bu kilme kısaca "talih, uğur, bereket" kelimeleriyle karşılanmaktadır. Saadetin bakış açısına göre değişebileceğini belirten Aristo, bu kavramı insanın ulaşmak istediği en son amaç kabul etmektedir. Hastaya göre mutluluk ve sağlık, fakire göre zenginlik ulaşılmak istenen en son amaç olabilir. Bununla birlikte maddi hazlar duyulara hitap ettiğinden farklılıklar arz edebilir ve bunlar en son amaç olmamalıdır. İnsan akıl sahibi bir varlıktır ve ne kadar makul ise o kadar mutlu olacaktır. Bundan dolayı mutluluk ruhun akla uygun davranışı ya da ruhun fazilete uygun herhangi bir davranışıdır. Çünkü insanın bütün değerli faaliyetlerinin iki kaynağından biri fazilet, diğeri akıldır. Diğer canlılarda bulunmayan akıl, insana ait bir özellik olarak düşünüldüğünden yaşanması mümkün olan en mutlu hayat düşünce ve idrak hayatıdır. Düşünce hayatı şehvet, öfke gibi kötülük kaynağı duygular tarafından kirletilmesi mümkün olmayan bir hayattır. Aklını en iyi biçimde kullanan ve kendini tamamen düşünceye veren kimse fillozof olduğuna göre en mükemmel mutluluğa filozoflar sahiptir (Çağrıcı 2008: 319).

Eski Uygur Türkçesi metinlerinde esen, esenlik, eseyülüg, ènç,

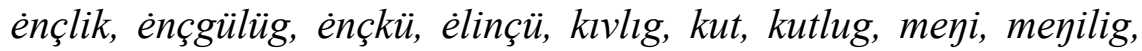
ögrünç, ögrünçü, ögrünçlüg, ögrünçülüg, sevinç, tınç, utll; edgülüg

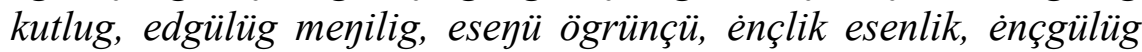

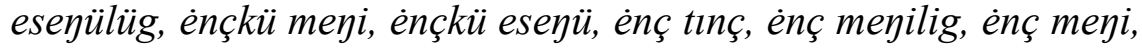
ènç ènçgülüg, ènç esen, kut buyan, kutul- mantıl-, kutlug ülüglüg, kutlug kıvlıg, kutad-asıl-, kut ülüg, kut kıv, küçlüg kutlug, meฑi 


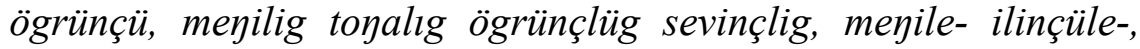

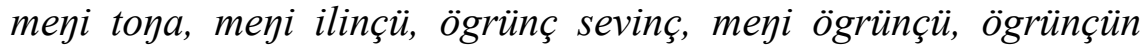

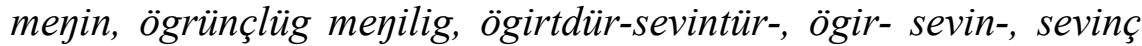
ögrünç, sevinçlig ögrünçülüg, sevinç utlı kelime ve kelime grupları ile yer alan saadet Aristocu anlayışın bir benzeri olarak kendini göstermektedir. Bu belgelerde mükemmel mutluluk Buda saadeti'dir.

ötrü olar terk ödün sansartakı togmak ölmeklig tod tolvı açıg emgeklerintin ozup kutrulup tejesizin yeg üstünki burhanlar edgüsine tegdeçi bolurlar (Kaya 1994: 23-24 38-39/22-23-1-4) "Onlar hızlı bir şekilde Saṃsāra'daki doğumlu, ölümlü (her) sefil ${ }_{2}$ acının verdiği sıkıntıdan kurtulup ${ }_{2}$ eşsiz, üstün ${ }_{2}$ Buda saadetine ulaşırlar."

inçe kaltı bügü biliglig burhanlar nirvanka kirü yarlıkamışlarınta kèn kut kolunmaklıg erksinmekleri küçinte adruk adruk adınlarka asıg tusulug ulug iş küdüglerig tükel bütürü yarlıkamakları neteg erser ançulayu ok nom kèrtünüy kértüsi kèrtüde kèrtü bilge bilig küçinte erkinçe tapınça adıra işlegülük iş küdügke

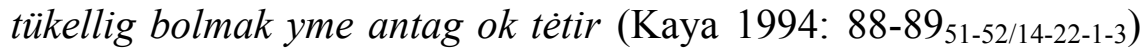
"Böylece bilge ${ }_{2}$ Budalar Nirvāṇa'ya girmeyi vazettikten sonra saadet isteklerinin artmasıyla ayrı ayrı başkalarına faydalı ${ }_{2}$ olacak büyük işleri ${ }_{2}$ tamamıla bitirip vazetme sonucunda kanun gerçeğin gerçeği ve gerçek doğru bilgi ${ }_{2}$ sayesinde işlenecek ve iş güç tam olarak yapılacaktır." (Tokyürek 2019: 62).

ol buyan küçinte üstün teyri yérinte altın yalayuk etözünte

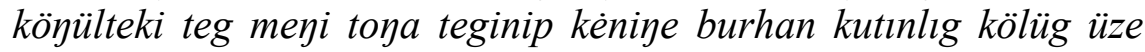
nirvanlig konuklukta konar "o sevap sayesinde üstte tanrı yerinde, altta insan bedeninde, gönlünden geçirdiği saadete erişip, sonrasında Buda saadetinden ibaret taşıtla sonsuz huzurdan oluşan konukluğa konar" (S. Şen 2002: 193).

Metinlerde birbirinden farklı pek çok kelime ile karşılanan saadet/mutluluk kavramı Türkçenin hemen her döneminde bu anlamiyla yer alan "kut" kelimesidir. "kut" Türk dilinin en eski kelimelerindendir. Aynı zamanda geçmişten günümüze töre/kanun ve èl/devlet kavramları ile hep yan yana kullanılmış kelimemizdir.

teyridem kut buyan utmak yejgedmek kentün ormantı "ilahi saadet ve üstünlük kendiliğinden yerlești” (S. Şen 2002: 179).

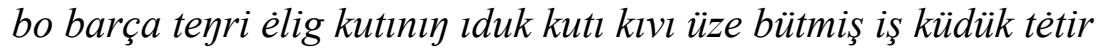


"bu, bütünüyle yüce hükümdar hazretlerinin kutsal kutı sayesinde tamamlanmış iş güçtür” (Ölmez 1994: 66 1436-1438).

tègin kutı ülügi üçün adasız tudasız kaç kün içinte erdinilig otrogka tegdiler "prensin kutu ve talihi sayesinde tehlikesiz ve engelsiz olarak birkaç gün içinde mücevher adasına eriştiler" (Hamilton 1998: 27 XXXIII).

bitig okıp iş işleser yėtinç uguşka tegi alku kutadur asılur "kitap okuyup iş işlese, yedi sülalesine dek bütünüyle saadet bulup payidar olur" (Bang-Gabain-Arat 1934: 130330-301).

koşar koşar buyanlıg yèti erdinilig kut tagda kutlug kıvlıg vaçirazan vajirlı örgünnüy kutulu mantılu turur (Kaya 1994: $350_{681 / 6-8}$ ) "Sayısız sevapl1, yedi mücevherli saadet dağında, kutlu elmas işlemeli tahtıyla (etrafını) mutlu ederek durur".

Eski Uygur Türkçesi metinlerinde saadetin genel olarak kut ile karşılandığı ve dharma/Buda'nın kaynaklık ettiği bu durum bize "kut"un hak eden kağana tanrı tarafından verilmesi geleneğini hatırlatmakta ve bu üç kavramın geçmişten günümüze birbirinin ayrılmaz bir parçası olduğunu bir kez daha hatırlatmaktadır. Devlet-adalet-saadet (èl-törü-kut) her zaman birbirine kaynaklık etmiş, bu durum Türk dilinin her döneminde verilen eserlere yansımıștır. Zaman zaman farklı konulara açıklık getirmek için farklı bağlamlarda kullanılan bu kavramlar bazı hikâye ve anlatılarda kuttörü-èl geleneğinin uzantısı olarak birlikte yer almaktadırlar.

\section{Eski Uygurca Metinlerde Devlet-Adalet-Saadet}

Eski Uygurcanın önemli eserleri arasında yer alan Altun Yaruk'un VIII. Tegzinç 20. Bölümü èligler haylarnıり köni törüsin aymak "Hükümdarların doğru kanununu söylemek" bölümü Eski Uygurlarda devlet-adalet-saadet konusunun tasviri gibidir.

Yirminci Bölüm, yagız yèr hațunı vasundari'nin t(e)yri t(e)yrisi burhan'a şu şekilde bir ricada bulunması ile başlar:

... aț kötrülmiş ayagka tegimlig t(e)yrim birök bo yèrținçüte kayu kayu èl uluşdakı èligler hanlarnıり köni törüsi yok erser ötrü ol èligler hanlar <öz> èlin uluşın uz başlagalı .. bodunin karasin égitgeli .. k(e)ntü öz etözlerin ıduk orunların y(a)rutu yaltritu 
tutgalı umazlar .. küsüşüm ol atı kötrülmişe ulug y(a)rlıkançıçı köyülin yügerü kılu yarlıkap .. èligler hanlarka tutguluk köni törüg èl başlamak biligig körkitü y(a)rlıkgay erti .. kim bo yirtiçüdeki èligler hanlar yme anı eşidmek anı bilmek üze t(e)yrim sizi门 $y$ (a)rlıgııızça yértinçüke ulug asıg tusu kılzunlar èl orunın [y]ègedtürüp k(e)ntüleri ènç m[ej]ilig bodun kara emgeksiz tolgaksız [bolz] unlar tèp ötünti (Çetin 2017: 335-3371120-1141). "Ad1 yüce, saygıdeğer tanrım eğer bu yeryüzünde ülkedeki hükümdarların $_{2}$ doğru töresi yoksa o hükümdarlar ${ }_{2}$ kendi ülkesini $_{2}$ ustaca yönetemez, halk1 ${ }_{2}$ doyuramaz kendi bedenlerini, kutsal mekânlarını aydınlatamazlar $_{2}$. Ey adı yüce (tanrım), büyük, şefkatli (bir) gönül yükseltmeyi buyurup hükümdarların ${ }_{2}$ tutacağı doğru yolu, devlet yönetme bilgisini (bize) bahşediniz. Öyle ki tanrım bu yeryüzündeki hükümdarlar ${ }_{2}$ da onu işiterek onu bilerek sizin buyruğunla yeryüzüne büyük fayda sağlasınlar. Ülkelerini iyi hâle getirip kendileri huzurlu ${ }_{2}$, halklarl ${ }_{2}$ sikintısız $_{2}$ olsun tanrım." diye arz etti." (Çetin 2017: 335-338)

yer hatunı vasundari'nin bu ricası üzerine Buda ona şu hikâyeyi anlatarak konuya açıklık getirmek ister: Baladivaçi isimli büyük bir hükümdar, oğlu Somadivaçi'yi veliahtı olarak ilan etmeden önce ona babasının da kendisine anlattığı önemli bir devlet geleneğini aktarır. Bu gelenek raçaşast(l)r tègme törü bitig'dir.

monta bizin ilkide berü ulalu kelmiş ulug küçlüg m(a)habrahmi ulug ezrua t(e)yri a[y] muş èliglerke hanlarka tutguluk raçaşast(l)r tègme törü bitig bar "Ey oğlum Somadivaçi, en eskiden beri süregelmiş yüce, güçlü Mahabrahmi Brahma tanrının buyurduğu hükümdarların 2 uyması gereken Rajaşastra adlı öğreti kitabı var." (Çetin 2017: 338-339)

$\mathrm{Bu}$ kanun kitabı raçaşast(l)r tégme törü bitig devletin dayanağıdır. Baladivaçi, men ötrü ol raça[s]as[t](l)r törü [bitig]ke tayakligın èki tümen yıl başladım "Ben o Rajaşastra öğreti kitabına dayanarak ülkeyi yirmi bin yıl yönettim." şeklinde bu geleneğin önemini vurgular ve oğlunun da bu kanun kitabı doğrultusunda devleti yönetmesini ister. (Çetin 2017: 340). Bu kanun (adalet) kitabı insanoğlunu mutlu etmek, onun saadetini sağlamak için, yeryüzündeki şüpheyi ortadan kaldırmak, bütün günahlara son vermek içindir (Çetin 2017: 342). 
Söylev, bu kanunun uygulanmadığı ya da dikkate alınmadığında karşılaşılan durum izah edilerek devam ettirilir. Hükümdar devlete ve ülkeye hâkim olmalıdır. Ülke içindeki vatandaşların günah işlemelerine boş vermesi hatta uykuya dalmış gibi devlet işleri ile meşgul olmaması kabul edilemez. Doğru kanun doğrultusunda hareket etmesi, bütün iyi kanunlar doğrultusunda temiz bir şekilde (devleti) derleyip toparlaması gerekir. Eğer kötülükleri görüp de müdahale etmez ise memleketinin içinde yalan ve hile arttıkça artar. Yine hükümdar memleketi için halkın kötü davranışlarına göz yumarsa tanrıların muhabbetini kaybeder. Böylece devletin kanunu daha da bozulur, kanun bozuldukça insanlar arasında yalan, hile ve kötülük daha da yayılmaya ve memleket daha da bozulmaya başlar (bk. Kaya 1994 ve Çetin 2017).

Hükümdarlar saraylarında oturup doğru kanunu bir tarafa bırakarak bozulmuş, tahrif edilmiş kanun ile halkı yönetirlerse tanrılar bir araya gelerek bu hükümdarlara lanet okuyarak " $\mathrm{Bu}$ hükümdarlar kanunsuz iş yaptılar, kötü (liyakatsiz) kişileri (devletin) içine alarak onları yakınlarında tuttular. Bu hükümdarların iktidarı uzun bir iktidar olmaz." diye konuşurlar. Tanrıların bu şekilde lanet okumaları ile o ülke tahrip olup ortadan kalkar (bk. Kaya 1994 ve Çetin 2017).

Devleti doğru kanuna göre yönetmeyen hükümdarların hem ülkesini hem de halkını nasıl büyük sıkıntılara soktuğu uzun uzun anlatılmaktadır. Diğer taraftan yine bu bölümde köni nomça, köni uz törü yolınta devleti yöneten hükümdarların ülkesi tanrıların da onları desteklemesi ile ol èl hanıg üzüksüz .. garhlar yultuzlar kuvragl .. öz yorlginça yorlyur .. künli aylı ordular .. kolu[sın] teyin şaşurmaz .. yumşak y[él]ler yèltirer .. tüz keẓigçe üdinçe özgen yagmur tökülür .. üd èyinki koluça .. tarımış ı tarıg tüş̧ yémiş .. alku barça uz büter èlte uluşta kişike .. aç kız emgek bultukmaz .. kamag t(e)yriler kuvragı üdün üdün yèvilür.. tolu tükel kolusuz .. uz ordulart içinde .. (Çetin 2017: 388-389 1645-1658) satırlarında yer aldığı gibi halkın refah içinde yaşadığı bir ülke hâlini alır.

Buda'nın yèr hatunı vasundari'ye Hükümdar Baladivaçi ile Prens Somadivaçi arasındaki diyaloglardan hareketle anlattığ Raçaşastır tégme begler törüsin "hükümdarlar kanunu" adil hükümdarların adaletle hükmettiği devletin temelidir. Adalet ile yönetilen devlet ise toplumun, halkın saadet bulduğu sistemdir. 
Adaletin her yöne sirayet ettiği toplumlarda halk da hükümdar da mutludur. Bu devletlerin ömrü uzun, yöneticileri ve halkı ise "devletlü ve saadetlü” bir șekilde yaşarlar. Bunun aksi durumunda ise tıpkı Altı Dişli Fil hikâyesinde olduğu gibi ortada ne devlet ne adalet ne de saadet kalır.

Hikâyede Kraliçe Bhadrā'nın kendi hırsları uğruna Altı Dişli Fil'i öldürmek için sürekli planlar yapması ve devletin başı olan hükümdar Brahmadatta'yı kandırması devletin çöküşünün ilk aşamasıdır:

ötrü ol badra hatun öyre ajuntakı yavlak sakınç tıltagınta montag osu<g>lug ögretig klltı kunçuylarnıı isiz yavaz sakınçın uzun turkaru br(a)hmadatè èligke yalganturur erti .. (Elmalı 2019: 5871-76). "Sonra Kraliçe Bhadrā, bir önceki varlığındaki kötü düşüncelerinden dolayı şöyle bir âdet edindi: (Kraliçe Bhadrā), kadınlara has kötü ve şeytani düşüncelerle sürekli ${ }_{2}$ Hükümdar Brahmadatta"yı kandırıp dururdu."

Bhadrā'nın kişisel arzularına hizmet eden ülkede adaletin yerini korku kanunu almıştır:

anta ötrü br(a)hmadatè èlig keyikçilerig okıp .. amrak kunçuy badra hatunnuy tüşemiş tülin èyin kezigçe tükel olarka sözledi .. birök meniך bo işimin bütürser sizler ulug türlüg açıg agrık bar .. bütürü umasar sizler yétinç uguşuฤuzlar birle yok yodun kılur m(e)n (Elmalı 2019: 6092-99). "Bunun üzerine Hükümdar Brahmadatta avcıları çağırdı. Sevgili Kraliçesi Bhadrā'nın gördüğü rüyayı düzgün bir şekilde büsbütün onlara anlattı. (Onlara): "eğer benim bu işimi hallederseniz, (sizin için) çok çeşitli ödüller ${ }_{2}$ olacak. Halledemezseniz (gelecek) yedi neslinizle birlikte sizi ortadan kaldırırım" dedi (Elmalı 2019: 9092-99).

Devletin gücü tehlikeli ve zararlı bir güce dönüşmüştür:

ol küni bilig tıltagınta [ol küçi tülüki] bo monı teg yavlak ada birle tuşurdı (Elmalı 2019: 73 $225-226$ ). ... O (Kraliçe Bhadrā), kıskançlığından dolayı (elindeki) gücü 2 bu şekilde tehlikeli ve zararlı (bir şeye) dönüştürdü (Elmal1 2019: 92225-226).

Adaletin olmadığ1, mutluluğun yerini korkunun aldığ1 ülkede son elbette felakettir: 
"Șaḍdanta ölür ve Buda mertebesine ulaşır. Avcı Kraliçenin yanına dönerken, filin dişlerini taşıdığı elleri kollarından düşer ve çürüyüverir. Yeni taht yapılmıştır. Fakat Bhadrā, bu yeni tahtta oturduğunda tahtın üzerinde ölür ve cehenneme gider. Brahmadatta'nın krallığı türlü felaketlerle ve saldırılarla yıkılıp yerle bir olur." (Elmalı 2019: 42-43).

\section{Sonuç}

İnsanlar arasında adaleti kurmak ve dolayısıyla insanların huzurunu sağlamak amacina yönelik toplumsal bir teşkilatlanma olan devlet "èl” Eski Uygurca metinlerde kut ve törü/nom kavramları ile yan yana yer almıştır. Bu kavramlar Budist kültürünün etkisiyle Eski Uygurca metinlerde Teyri Burhan-nom törü (Dharma)-Burhan kutı ile sembolleştirilmiştir. Bu metinlerin büyük bir çoğunluğu dinî metinlerdir. Halka hitap etmek, onları Buda saadetine ulaştırmak bu metinlerin en önemli amaçlarıdır. Metinler her ne kadar soyut bir Buda/Budizm ideali ortaya koysalar da öğreti metinlerindeki örnek hikâyelerde ve diğer anlatılarda günlük yaşama dair göndermeler de vardır. Sivil belgeler ise doğrudan hayata dair metinlerdir ve bu metinlerde her üç kavramın somut karşıllı̆ 1 doğrudan görülebilir. Gerek Budist Uygur dinî metinlerinde gerekse sivil belgelerde devlet-adalet-saadet kavramlarının ele alınışı Uygurların eski Türk geleneğindeki Teyri-törü-kut anlayışının farklı bir şekilde yansımasıdır. Gelenek devam etmekte fakat Uygurların içine girmiş oldukları yeni kültür dairesi geleneğin tarzını değiştirmektedir. Tẹri-törü-kut anlayışı Budist kültürden hareketle Burhan-nom törü (Dharma)-Burhan kutı anlayışı ile varlığını devam ettirmiştir.

\section{Kaynaklar}


Arat, R. R., 1987: “Eski Türk Hukuk Vesikaları”, Makaleler, Haz. Osman Fikri Sertkaya. Ankara: TKAE Yayınları.

Bang, W., A. von Gabain, G. R., Rachmati, 1934: Türkische Turfantexte VI Das buddhistische Sūtra Säkiz yükmäk. Berlin: Verlag der Akademie der Wissenschaften.

Caferoğlu, A., 1934: "Uygurlarda Hukuk ve Maliye Istılahları". Türkiyat Mecmuası, S. 4, s. 1-43.

Çağrıc1, M., 1988: “Adalet" Türkiye Diyanet Vakfi İslam Ansiklopedisi, C. 1, İstanbul, Y11: 1988, s. 341-343.

Çağrıc1, M., 2008: "Saadet" Türkiye Diyanet Vakfi İslam Ansiklopedisi, C. 35, İstanbul, Y11: 1988, s. 319-322.

Çetin, E., 2017: Altun Yaruk Sekizinci Kitap. Berlin Bilimler Akademisindeki Metin Parçaları, Karşılaştırmalı Metin, Açıklamalar, Dizin, Adana: Karahan Kitabevi.

Davutoğlu, A., 1994: "Devlet", Türkiye Diyanet Vakfi İslam Ansiklopedisi, C. 9, İstanbul, Y11: 1994, s. 240-241.

Elmalı, M., 2019: Eski Uygurca Altı Dişli Fil Hikayesi, Ankara: TDK Yayınları.

Golden, B. P., 2002: Türk Halkları Tarihine Giriş. Çev. Osman Karatay, Ankara: KaraM Yayınları.

Hamilton, J. R., 1998: Çev. Vedat Köken, Dunhuang Mă̆arasında Bulunmuş Buddhacılı̆̆a İlişkin Uygurca El Yazması Iyi ve Kötü Prens Öyküsü, Ankara: TDK Yayınları.

İzgi, Ö., 1986: Kutluk Bilge Kül Kağan- Bögü Kağan ve Uygurlar, Ankara: Kültür ve Turizm Bakanlığı Yayınları.

Kaya, C., 1994: Uygurca Altun Yaruk Giriş, Metin ve Dizin, Ankara: TDK Yayınları.

Köseoğlu, N., 1997: Devlet-Eski Türkler'de, İslam'da ve Osmanlı'da, İstanbul: Ötüken Yayınları.

Ögel, B., 1982: Türklerde Devlet Anlayışı (13, Yüzyıl Sonlarına Kadar), Ankara: Başbakanlık Basımevi.

Ölmez, M., 1994: Hsüan-Tsang'ın Eski Uygurca Yaşamöyküsü VI. Bölüm, Hacettepe Üniversitesi, Sosyal Bilimler Enstitüsü Yayımlanmamış Doktora Tezi, Ankara. 
Ölmez, M., 2017: Köktürkçe ve Eski Uygurca Dersleri, İstanbul: Kesit Yayınları.

Özyetgin, A. M., 2014: İslam Öncesi Uygurlarda Toprak Hukuku, İstanbul: Ötüken Yayınları.

Şen, A., 2004: Uigurische Sprachdenkmäler'den Seçme Uygur Hukuk Belgeleri, İstanbul Üniversitesi Sosyal Bilimler Enstitüsü yayımlanmamış Yüksek Lisans Tezi, İstanbul.

Şen, S., 2002: Eski Uygur Türkçesinde İkilemeler, Ondokuz Mayıs Üniversitesi Sosyal Bilimler Enstitüsü Yayımlanmamış Yüksek Lisans Tezi, Samsun.

Şen, S., 2007: Orhun, Uygur ve Karahanl Metinlerindeki Meslekler Bağlamında Eski Türk Kültürü, Ondokuz Mayıs Üniversitesi Sosyal Bilimler Enstitüsü Yayımlanmamış Doktora Tezi, Samsun.

TDK Güncel Türkçe Sözlük https://sozluk.gov.tr

Tekin, Ş., 1976: Uygurca Metinler II Maytrisimit Burkanclların Mehdisi Maiterya ile Buluşma Uygurca Íptidẩ Bir Dram, Ankara, Sevinç Matbaası.

Tekin, Ş., 1980: Maitrisimit Nom Bitig, Die uigurische Ubersetzung eines Werkes der Buddhistischen VaibhasikaSchule, 1. Teil: Transliteration, Ubersetzung, Anmerkungen. Berlin: Akademie der DDR. Zentralinstitut für alte Geschichte und Archäologie. (Schriften zur Geschischte und Kultur des Alten Orients. Berliner Turfantexte. 9).

Tokyürek, H., 2018: Altun Yaruk Sudur IV (Karşılaştırmalı Metin Yayını). Tegzinç, Ankara: TDK Yayınları.

Tokyürek, H., 2019: Eski Uygur Türkçesinde Budizm ve Manihaizm Terimleri, Ankara: TDK Yayınları.

Zieme, P., 2000: Vimalakurtinirdesasutra. Edition alttürkischer Übersetzungen nach Handschriftfragmenten von Berlin und Kyoto, Berlin: Berlin-Brandenburgische Akademienvorhaben Turfanforschung, (Berliner Turfan Texte 20). 